\title{
Mustard Gas Massacres and Atrocities Committed by Italy in 1939 Against the Inhabitant of Menz, Merhabete, and Jamma in Amesegna Washa/Zeret Cave
}

\author{
Gashaw Ayferam Endaylalu \\ Debre Brehan University, Debre Berhan, Ethiopia
}

\begin{abstract}
Following the 1934 Wal Wal incident which was used as a pretext for the second Italo-Ethiopian war, Italy had used prohibited chemical weapons in different battles. Among the chemical warfare agents Italy had used mustard gas, the most deadly poison gas and chemical available, against Ethiopian fighters. Nevertheless, the five year Italian rule over Ethiopia was not a peaceful experience of colonial rule. They were continuously harassed by Ethiopian patriots and had to live entrenched in their isolated fortifications. Sadly, Italy had committed several crimes against humanity. In this case, Ametsegna Washa, some call it "the cave of Zeret” was one of the forgotten massacres which happened in 1939, where up to more than 5,500 Ethiopians were gassed and machine-gunned. This paper, therefore, attempted to describe and analyze the forgotten massacres of the inhabitant of Menz, Merhabete, and South Wollo provinces in Ametsegna Washa (The cave of Zeret) by Fascist Italy in 1939. In doing so, the study employed qualitative research in which empirical data were collected from primary and secondary data. Primary data were gathered through qualitative field research observation, key informant interview with direct victims and their descendants, elders and experts at Menz keya gebreal woreda tourism office. Secondary data were gathered from books, published and unpublished journals, and historical records of the patriot. In view of that, the study employed qualitative method of data analysis in particular descriptive narration. The findings of the study shows that through the approval of Badoglio to use chemical weapons, the fascist soldiers had thrown several barrel with a mustard gas through the mouth of the cave then they attacked the mouth of the cave with artillery and machine-gun fire, and as a result more than 5,500 peoples have lost their live while those escaped from the massacre had faced a number of problems. The survival of the catastrophic massacre had faced physical injury which includes blindness, skin related problem, respiratory problem and as a result they had lived their remaining age with misery. This study, therefore, calls for the need of further investigation in the area. Along this, the place is not well-protected and, therefore, the government as well as the other concerning bodies should give serious attention in preserving and memorizing the historical cave.
\end{abstract}

Keywords: Ametsegna Washa, mustard gas, state responsibility, Ethiopia, Italy, Menz, five year Italy occupation

\section{Introduction}

The 1896 Adwa victory and subsequent adoption of October 1896 Italo-Ethiopian Peace Treaty, a treaty

Gashaw Ayferam Endaylalu, MA in International Relations and Diplomacy, Lecturer at the Department of Civics and Ethical Studies, College of Social Science and Humanities, Debre Brehan University. 
that nullified the Wuchale Treaty and recognized the absolute sovereignty of Ethiopia, had never made Italy to cease its plan of colonizing Ethiopia. Rather Italy was in search of a legal and moral ground, material preparation and international backing for the imminent war of invasion over Ethiopia. During the interlude period, Italy had made several agreements ${ }^{1}$ with colonial powers which undermined Ethiopia's independence and territorial integrity. All the agreements foreshadowed Italy's incessant colonial ambition; even some writer calls the agreements "the magna carta” of Italian aspirations in Ethiopia' (Zewude, 2002). Along the normative route, Italy also followed "policy of subversion” and "policy of persuasion” aimed at colonizing Ethiopia through diplomacy. In the year 1934 Italy had ensured the fulfilment of the diplomatic condition, what was required to open war of invasion was a pretext, a casus belli. This came when the Italian colonial army and Ethiopian troops clashed at Walwal, a post about 100 kilometres inside of Ethiopian territory from the border between Ethiopia and the Italian Somaliland. To add insult to injury, Mussolini unreasonably demanded apology and compensation from Ethiopia that the Ethiopian government rejected this and revoked the 1928 Italo-Ethiopian treaty while still believing to resolve the problem through diplomacy.

Making the Walwal incident as a pretext, a casus belli, the Fascist Italian Government however started the war of invasion on 3 October 1935. Because of modern military equipment including mortars, tanks, artillery, machine-guns, sophisticated air force and internationally prohibited mustard gas and mobilized askaris from Libya, Eritrea, and Italian Somaliland, Italy became victory while Ethiopia had failed in repeating the Battle of Adwa (Zewude, 2002). From the legal perspective, Italy's Invasion of Ethiopia was violation of international law including those treaties for which Italy was signatory i.e. the October 1896 Italo-Ethiopian Peace Treaty, the 1928 Italo-Ethiopian Treaty of Friendship , and the 1919 League of Nations Convention.

The Italy victory at the battlefield had resulted Italy's five year occupation of Ethiopia. On the side of Ethiopia, internal patriotic resistance and external diplomatic campaign were the strategies being employed to fight against the colonizer. The five year Italian rule over Ethiopia, however, was not a peaceful experience of colonial rule. Rather they were continuously harassed by Ethiopian patriots.

Nevertheless, during the course of the war and in the post-war five year occupation period Italy had committed savage war crimes including use of internationally prohibited mustard gas, genocide, torture, poisoning of water and killing thousands of peoples. Italy's war crime includes the use of internationally prohibited mustard gas through airplane in Tekezze, Al-amba, Debenatin, Debre Tabor, Sekota, Korem, Ashengie (Mamo, 2009), and through throwing 12 barrel in Ametsegna Washa (Mamo, 2009); one million Ethiopians killed including 30,000 murdered within three days in Addis Ababa alone; over 300 monks and clergy killed at Debre Libanos monastery; two Ethiopian Orthodox church bishops: Abune Petros and Abune Michael killed; 2,000 Ethiopian Orthodox Churches destroyed; 525,000 homes destroyed; 14 million animals killed; an environmental disaster from the poison gas sprayed throughout Ethiopia, and the looting of numerous treasures including over 500 historical documents and the Emperor's only airplane known "Tsehay" currently exhibited at the Italian Air Force Museum (2015).

Even though all the aforesaid atrocities are horrific, the mustard gas massacre in Ametsegna Washa also called the cave of Zeret was shockingly cruel and inhumane. It was, to use Leo Kuper's word, genocidal massacre. This massacre was the undocumented and forgotten massacre. Sadly, the cave is not conserved well. This study, therefore, attempted to open a new avenue of discussion by revealing the mustard gas massacre of

11906 Tripartite agreement, 1925, Italy signed a bilateral agreement with Britain. 
the inhabitatnt of Menz, Jamma, Merhabete, and Jiru in Ametsegna Washa in 1939 and thereby call for the imperative of Italy and Vatican apology and adequate reparation.

\section{Methods of the Study}

This study revealed mustard gas massacres and atrocities committed by Italy in 1939 against the inhabitant of Menz, Merhabete, and Jamma in Amesegna Washa/Zeret Cave. To properly address the issue under investigation, the study employed a qualitative research methodology: "a research strategy that usually emphasizes words rather than quantification in the collection and analysis of data” (Bryman, 2012, p. 380). As quality is about "the what, how, when, and where of a thing its essence and ambience" then qualitative research focuses on the "the meanings, concepts, definitions, characteristics, metaphors, symbols, and descriptions of things" (Berg, 2001, p. 3). It employs a distinctive method of data collection, analysis, and interpretation. Thus, in qualitative research, the researcher must collect data from documents, observing certain behaviours and interviewing selected participants by using different techniques (Creswell, 2009, p. 176; Kothari, 2004, p. 5). Moreover, qualitative researchers use a theoretical perspective through which they attempt to understand and examine the social, political, and historical context and complexity of the issue under study. In its very nature, qualitative research is also interpretive which means that the researcher first will analyse and make sense of the collected data and interpret it to have meaning and finally draw a conclusion (Creswell, 2009, pp. 175-176).

In this study, a qualitative research methodology is justifiable due to the nature of the research problem, objectives, and questions under study. In view of that, the study had used multiples sources of data such as interviews, life stories, public documents and recordings, and other pertinent secondary sources. The instruments employed to gather primary data are in-depth interview with victims and their families, life story, and qualitative filed research observation ${ }^{2}$. Finally, the researcher analyzed the collected data through descriptive narrative analysis.

\section{Use of Chemical Weapons in the War: History, Issues, and Legality}

The use of hazardous chemical and biological agent in battlefield dates back to ancient time (Szinicz, 2005). However, the first recorded use of chemical agents in terms of weapons of mass destruction goes back to World War I, when on April 22, 1915 large amounts of chlorine were released by German military forces at Ypres, Belgium.

There are different substances or chemical agents that cause chemical-weapons injuries and deaths during World War I: chlorine, phosgene, and mustard gas. Of these substances, mustard gas, a potent blistering agent, was labelled as "King of the Battle Gases", because it eventually caused more chemical casualties than all the other agents combined, including chlorine, phosgene, and cyanogen chloride. On the other hand Global Security Organization stated that mustard is viewed as "king" of agents because of its ease of production, low cost, predictable properties, persistence, and ability to cause resource-devouring casualties rather than fatalities. Mustard on the skin causes no immediate sensation and symptoms normally do not appear until several hours after exposure. At incapacitating levels this may be as long as 12 hours. All in all, it was the most deadly poison gas and chemical warfare agent which is commonly associated with World War I (Brophy \& Fisher, 1959). Regarding its composition and color, Balszuweit et al. (2008, p. 313) stated that,

${ }^{2}$ The researcher had visited the cave two times with international researchers in mid-of February 2017 and 2018. 
Sulfur mustard is an oily liquid with poor solubility in water and a high solubility in organic solvents. Its color varies from light yellow to dark brown, depending on the technical impurities of the compound. Its freezing point lies between $13^{\circ} \mathrm{C}$ and $14^{\circ} \mathrm{C}$ and its boiling point between $215^{\circ} \mathrm{C}$ and $217^{\circ} \mathrm{C}(760 \mathrm{~mm} \mathrm{Hg})$.

Mustard gas is also referred as a bifunctional alkylating substance being used as chemical warfare agent (vesicant). Mustard gas is deployed as a brownish-yellow vapor with an odor similar to that of garlic, horseradish, or mustard. It can cause serious damage to the respiratory tract and eyes and produces life-threatening blisters on the skin. If a victim of mustard gas exposure receives medical treatment shortly after contact with the agent, survival is likely.

Table 1

Physicochemical Properties of Sulfur Mustard

\begin{tabular}{ll}
\hline Chemical formula & \multicolumn{1}{c}{$\mathrm{C}_{4} \mathrm{H}_{8} \mathrm{Cl}_{2} \mathrm{~S}$} \\
\hline Appearance & Oily liquid, light yellow to dark brown \\
Odor & Mustard, garlic, and onion \\
Molecular weight & 159.08 \\
Liquid density & 1.27 (specific gravity) \\
Freezing point & $13^{\circ} \mathrm{C}-14^{\circ} \mathrm{C}$ \\
Boiling point & $215^{\circ} \mathrm{C}-217^{\circ} \mathrm{C}$ \\
Volatility (mg/m $3,20^{\circ} \mathrm{C}$ ) & 610 \\
Solubility & Poor in water, high in ethanol \\
\hline
\end{tabular}

Note. Source: Balszuweit et al., 2008.

Mustard gas also produces cutaneous blisters, respiratory and gastrointestinal tract injury, eye lesions, bone marrow depression, chronic obstructive lung disease, lung fibrosis, recurrent corneal ulcer disease, chronic conjunctivitis, abnormal pigmentation of the skin, and different forms of cancer. These health effects are confirmed at different battlefields where mustard gas is used.

In history, the first-ever large scale usage of chemical agents was used during WWI. Because of the scientific mobilization, development, production, and deployment of war gases such as chlorine, phosgene, and mustard, the war was referred as the chemist's war. The first usage of mustard gas was reported to be on April 22, 1915, which is used by German Forces at Ypres, Belgium (Szinicz, 2005). Germany had used a lung-damaging agent chlorine often referred. Germany's use of chlorine gas was identified as use of weapon of mass destruction as a result of its intentional use to cause severe injuries. On July 12/13, 1917, Germany had used for the second time but the first ever large scale use skin damaging agent bis (2-chloroethyl) sulfide (sulphur mustard). Germany's use of mustard gas was followed by France and the United Kingdom. In 1917, the British military uses chemical weapons against the Germans at the Battle of Loos.

The horrific result of chemical agents that was used during WWI resulted the Protocol for the Prohibition of the Use in War of Asphyxiating, Poisonous or other Gases, and of Bacteriological Methods of Warfare-often called the Geneva Protocol. It was signed at Geneva on 17 June 1925 and entered into force on 8 February 1928 (U.S. State Department, n.d.). This treaty has prohibited the use of chemical and biological weapons in international armed conflicts. The treaty reaffirmed the pre-war prohibition of the use of poisonous gases of the 
Hague Declaration of 1899 and the Hague Convention of 1907 which forbade the use of "poison or poisonous weapons" in warfare. Both Italy and Ethiopia were signatory states.

Although use of whatever chemical and biological agents at battlefield condemned, chemical weapons continued to be developed even used during the interwar years. On the eve of Geneva Protocol, Spanish had used mustard gas in 1934 against Riffian Berber rebellion in Morocco led by guerrilla leader Abd el-Krim (Paige, 2009). Ten years after the Geneva Protocol had been signed, the use of chemical weapons on a large scale occurred once more such as Italy in Ethiopia, British in Russia and Iraq, and the Japanese in China. The more blatant violation of the Geneva Protocol and use of mustard gas was came when Italy used it during the second Italo-Ethiopian war of 1935-1936. Both states were signatory states. However, Italy had committed war crimes and used prohibited chemical agents of which the most deadly available poisonous gas, mustard gas had been used. The following section reviewed Italy's use of chemical agents most often mustard gas during the war and post-war five year Italy occupation of Ethiopia.

\section{Fascist Invasion of Ethiopia and Subsequent Use of Mustard Gas}

Italy has never ceased its colonial ambition over Ethiopia even after the victory of Adwa. During the inter-war period, Italy was engaged in logistic, technological, and chemical weapon preparation for the imminent war with Ethiopia. Only shortly from 1930-1933 Italian official policy on Ethiopia waned as Mussolini's prime concern turned to Europe, to create a "greater Political Europe" in which Italy would assume leading role. Mussolini proposed "a four-power pact” (of Britain, Germany, France, and Italy) with the intent to create "an alternative to the League". But the plan had successfully failed due to the rejection by Britain and France in which they were playing leading role and Hitler of Germany was not also willing to accept Mussolini's scheme.

As a result, Mussolini turned to Africa and sought aggressive war against Ethiopia to retaliate Italy's defeat at Adwa in 1896 and also to restore the power and glory of Rome by creating a colonial economy in East Africa. For the sake of not replicating the past Adwa defeat, Mussolini sought to use prohibited chemical weapons unless otherwise they are not sure of Italy's victory. For this he ordered the development and production of different chemical weapons from 1930-1932 (Daniel, 2009). In these period, huge amount of chemical weapons were transported to Eritrea and Italy Somali Land for the imminent war of aggression against Ethiopia. Initially, a total of 56,000 canons had arrived at Eritrea since 1915 (Daniel, 2009). Along this, an internationally prohibited chemical weapons such as 45 ton C-500-T mustard gas, 265 ton other chemical agent, and 7,483 bombs filled with chemical agents were arrived in Eritrea and Somalia. Mussolini also ordered initially 2,108 bombs filled with C-500-T mustard gas. Later on commander of Italian forces requested additional another 1,000 mustard gas filled bombs.

Chemical weapons do not appear to have been used in the war until October 10 and 29 of 1935 which is the first-ever use against Ethiopia. Since this day, using chemical agents particularly mustard gas against Ethiopian soldiers, civilians, water bodies, grazing land and villages had become the common activities of Italian force commanders. From October 3, 1935-10, 1935 Italian aircraft dropped fluid 500 ton chemical agent filled bombs. In December 1935 Italian aircraft dropped tear gas grenades and asphyxiating gas over the Takkazze River. In February 22, 1935 Italy dropped 6 C-550-T mustard air bombs in Debeguna. From February 23-27, 60 sulphur mustard air bombs were dropped in different areas. 
In the later year (1936), Italian aircraft dropped chemical agent bombs in Tekezze River on January 2 and 9 of 1936. Italy also used chemical weapons in the Battle of Shire, the Battle of Maychew , in the Lake Ashangi region, January 6 in Debenat and Debre Tabor, 14 March 1936 in Korem, April 4-7 in Korem (Daniel, 2009; Grip \& Hart, 2009). The last area was Ametsegna Washa in which a huge mustard gas was used in April 1939. 12 barrel filled with mustard gas was used in the cave (Daniel, 2009).

Table 2

Ethiopian Towns Attacked With Chemical Weapons in the Second Italo-Abyssinian War

\begin{tabular}{|c|c|}
\hline Town & Date of attack \\
\hline Takkaze & 22 Dec. 1935 \\
\hline Amba Alaa & 26 Dec. 1935 \\
\hline Borena & 31 Dec. 1935 \\
\hline Sokota & 10 Jan. 1936 \\
\hline Makale & 21 Jan. 1936 \\
\hline Megalo & Feb. $1936^{a}$ \\
\hline Waldia Road & 27 Feb. 1936 \\
\hline Quoram & 16 Mar. 1936 \\
\hline Ylanserer & 17 Mar. 1936 \\
\hline Quoram & 17-18 Mar. 1936 \\
\hline Irga Alem & 19-21 Mar. 1936 \\
\hline Indomahoni & 29-30 Mar. 1936 \\
\hline Quoram & 4-7 Apr. 1936 \\
\hline
\end{tabular}

Note. The exact day was not available to the Ethiopian Government. Source: League of Nations, Letter, dated April 13th, 1936, from the Ethiopian Representative to the Secretary-General, 13 Apr. 1936, League of Nations Official Journal, Annex 1592, Apr. 1936, pp. 479-480.

On the side of Ethiopia, it was reported and appealed to the League of National. Nonetheless, the League, incapacitated by the British and French appeasement policy toward Mussolini's Italy, failed to take any significant measure. The question returned back with empty hand with the exception of diplomatic and moral victory. The following section analysed the mustard gas massacre in Ametsegna Washa in Menz Keya Gebreal Woreda Zeret kebele.

\section{Fascist Genocide in Ametsegna Washa and the Quest for Justice}

Ametsegna Washa, literary mean Cave of Resistance, is found in Menz keya Gebreal woreda in Zeret Kebele of North Shewa, Amhra regional state. North Shewa was one of the typical centers of patriotic resistances fighters against the Italian occupation. Particularly, Menz, Yenugus Hager, Ye Amahara Minich, became the main center of patriotic resistance fighter due to the geographical advantage of the area, the place where Emperor Haile Selassie and other nobility's ancestors found and its historic linkage with Solomonic Dynasty.

Zeret has a geographical advantage linking Jamma, Keya, Merhabete, Jiru, and Lalo midir. Along this, the Emperor's grandfather birth place, Doba, is found $5 \mathrm{~km}$ of Zeret. Zeret kebele town is Kambo, which is derived from Italian Camp in that area. The people of Menz keya had lived the five year occupation in Ametsegna Washa. Later on patriotic resistance fighters from Jamma, keya, Merhabite and Jiru had joined and entered into the cave in April 1939. The cave was prepared well. They have all the material such as local food preparing 
tools such as Dist, sefed, enkib, moseb, mitad; local beverage preparing materials like gan, genbo, madiga, docho; water fetching like ensira and coffee preparing tools. There is also large number of cereal baskets including dibggnet and underground basket.

The cave has only one entrance gate. The end of the cave is not yet discovered. Even it is difficult too to prove it. On the left side of the cave there is water called Bahir. Even two rivers namely Shint and Setan Bahir, Devil River, also flowed through the mouth of the cave. The right side of the cave is filled by a number of Dibgnt, underground cereal basket, cloth made up of cotton and other food and beverage preparing tools. To enter into the second part of the cave it is must to pass-through very narrow path which requires traveling like Snake. After some 10-15 minutes it is possible to walk. However, entering the third part, where church property and other found, is risky. No one has attempted to enter into this part except the resistance fighter to keep properties. According to the informants, in this part there is large water called bahir surrounded by grass-qetema ${ }^{3}$.

A war between Italian forces from right high face of rock and the patriotic resistance fighter from the left and right mouth of the cave was fought for 12 days from end of February to April 8. For 12 days the Italian had used several tactics to enter into the cave. Even they attempted to attack the mouth of the cave through cannon. But the cave protected them as a shield. As a result, due to the locational advantage of the cave entering the cave was impossible. By drawing lesson from their failure, Italian had used bandas. As a result, there were peoples who leave the cave. Unfortunately the Italian violated their promise and Machine-gunned, slaughtered through Lolberet cliff and murdered them inhumanely.

However, all Italians effort had failed. Even at worst a large number of Italian soldiers were killed by the patriotic resistance fighters when they attempted to enter into the cave. Italian also wants to use aircraft mustard gas bombs. But the cave prevented the use of airplanes for delivering the gas and forced the fascist troops to resort to other methods. Consequently, they were in search of a more advanced and effective method. The tactic used by Italian was transferring the contents of the C-500-T bomb to 12 barrel. Then after, they rope the barrel by electric wire. According to an archeological study by González-Ruibal, Sahle, and Ayán Vila (2011):

the complex operation of bombing the cave was carefully described by the main protagonist, Sergeant Major Boaglio, whose memoirs were discovered by Matteo Dominioni. Boaglio was ordered to abseil at night the vertical cliff where the entrance to the cave opened (see Figure 9). At dawn on April 9, he threw a charge near the cave's entrance. Simultaneously, a $65 \mathrm{~mm}$ howitzer started to fire tear gas shells. Despite the hell into which the cavern must have been transformed, the Ethiopians resisted for another full day. Only at dawn of the 11th did they, not before attempting another escape the previous night.

According to the survivors, the barrel was thrown in the night which is an Easter day. During the night the Italian throw 12 barrel filled with mustard gas into the mouth of the cave from the second cliff called Gedam. On the morning of that day, Easter day, the Italian soldiers attacked the 12 barrel from the right side of the first cliff, Kelawuha around Dimdm Washa. They also continuously attacked the mouth of the cave with artillery and machine-gun fire.

Initially, there were no symptoms and difficulties associated the mustard gas. After nine hours, the gas became active and affected all peoples inside the cave. The number of affected peoples increased at 12 hours. It affected their eyes, skin, and respiratory system. Children, women, elders were entered into the next part of the

${ }^{3}$ Interview with Bishaw Tesema, Elifnesh tegene and others. 
cave to got protection but never survived. According to Bishawu Tesema, survivor of the massacre, at 12 hours even the patriotic fighters became unconscious, mad, and insanity. This was a very difficult condition for those who resisted the gas through the use of onion and their urine. It was difficult to control them even they take guns to kill those who are in the cave.

On the night of that day, Grazmach later dejazmach Teshome Shenkut decided to leave the cave. He gathered those resistance fighters who resisted the gas and escaped at night using several tactics. Along with Grazmach Shenku, Demeke Chufa (his home is kelawuha $3 \mathrm{~km}$ from the cave), Zemelak Wube (from Zeret), Welde-Tsadik Dosegna were the survivor. Fesese Tesema and Bishawu Tesema were also survived but left their life with eye blindness. After some days of the massacre, Italians entered the cave and murdered inhumanely those survived but in between life and death. According to the survivor, the total number of 5,500 lost their life due to the genocide committed by Italy. But there is different data with regard to this number. The Memory written by Dejazmach Teshome Shenkut estimates to be more than 3,000 thousands.

Generally, 5,500 peoples were died due to the mustard gas. This number may not include number of children and women. Along this, unknown number of cattle, goats, and sheep were died. When we see the health effect of mustard gas, those who survived faced respiratory system problem, skin related problem and most of them were blind. It has also unconfirmed environmental effect which can be remembered through Amharic poems:

$$
\begin{aligned}
& \text { We have no right to eat wheat } \\
& \text { It's the blood that the dead moths grow. }
\end{aligned}
$$

The mustard gas massacre also causes moral and psychological damage. The surrounding fertile land is not yet cultivated because the land is viewed as "land of blood". The cave also viewed as "cave of devil". Due to such conviction plus the difficulty to know the end of the cave, no one has the courage to enter the cave. Only few individuals would enter the cave.

Still today there are human body ruminants, clothes made up of cotton, cereal basket and gun. The archaeological remains revealed that women had been playing a crucial role in the war. As shown in the entrance part of the cave, there were tools and equipment used for food and beverage preparation. This shows that the task given to women is similar with the normal condition. There are also individuals who mandated to defend the cave. They will defend the cave from the left and right side of the cave. One of the cave defender was Bash Gelamt who was killed by Italy Force. One Italy commander asked him:

Gelemt how many Italian soldiers you killed?

Basha Gelamt replied that:

Don’t ask me! Ask my Mewuzer. At this time the commander ordered a soldier to kill him.

\section{The Quest for Justice: An Imperative of Cessation and Adequate Reparation}

As mentioned above Italy had committed war crime and her action was breaches of international humanitarian law. War crimes are serious violations of customary or treaty rules belonging to international humanitarian law (IHL) or international law of armed conflict. Under international humanitarian law, genocide, crimes against humanity and war crime are elements of crimes as stated in Articles 6, 7, and 8 of the Rome Statute (United Nations, 2005). Any action violating these listed crimes is considered as grave breaches of international humanitarian law. 
Italy had committed all elements of crime which includes genocide by killing, genocide by causing serious bodily or mental harm; crime against humanity of murder, crime against humanity of extermination, crime against humanity of torture; war crime of willful killing, war crime of torture, war crime of inhuman treatment, war crime of willfully causing great suffering, war crime of destruction and appropriation of property, war crime of attacking civilians, war crime of attacking civilian objects, war crime of excessive incidental death, injury, or damage, and war crime of attacking undefended places such as church and Monastery. Along this, Italy had used internationally prohibited mustard gas by violating international customary laws and the Geneva Protocol.

Under international law, Italy is a responsible state for the above elements of internationally wrongful acts committed by Italy during 1935-1941 in Ethiopia. “The Responsibility of States for Internationally Wrongful Acts" in 2001 which is adopted by International Law Commission (ILC) stated that "every internationally wrongful act of a State entails the international responsibility of that State” (United Nations, 2005). This means that state responsibility is a fundamental principle of international law which may be arising out of the nature of the international legal system and the doctrines of state sovereignty and equality of states; whenever one state commits an internationally unlawful act against another state, international responsibility is established between the two. In this regard, the legal consequences of an internationally wrongful act include cessation and non-repetition, and reparation for "the injury caused by the internationally wrongful act which would take either the form of restitution, compensation and satisfaction or in combination” (United Nations, 2005, Article 34).

Cessation and non-repetition obliges the responsible state for internationally wrongful act to cease the act in question, "if it is continuing and to offer appropriate assurances and guarantees of non-repetition" (Article 30). Reparation obliges the responsible state who commits war crime to make adequate reparation. According to Article 31 of the Articles on state responsibility provides that "the responsible state is under an obligation to make full reparation for the injury caused by the internationally wrongful act and that injury includes any damage, whether material or moral, caused by the internationally wrongful act of a state". The obligation to make reparation is governed in all its aspects by international law, irrespective of domestic law provisions.

According to Article 34 of the drafted document reparation to the victim can take either the form of restitution, compensation, and satisfaction, or in combination. Restitution in kind is the apparent mechanism of fulfilling the reparation, since it aimed at bringing what exist in the pre-war period. However, some disputant parties may justify their case by viewing restitution as cessation, but they are different. The obligation to end an illegal situation was not reparation but a return to the original obligation that is cessation of the illegal conduct.

Compensation is another mechanism of execution of state responsibility for an internationally wrongful act. Article 36(1) provides that if whatever damaged caused by an internationally wrongful act is not fulfilled worth by restitution, the state responsible is under an obligation to give compensation. Article 36(2) states that "the compensation to be provided shall cover any financially assessable damage including loss of profits in so far as this is established". The aim is to deal with economic losses actually caused. Damage includes both material and non-material (or moral) damage. Monetary compensation may thus be paid for individual pain and suffering and insults. In this case, compensation may be assessed on the basis of the "fair market value" of the property lost.

Satisfaction is the third form of reparation which can be labeled as non-monetary compensation. Satisfaction may consist of an acknowledgement of the breach, an expression of regret, a formal apology, or 
another appropriate modality.

In view of the above legal ground, Italy had not yet fulfilled its responsibility. On the one hand, Italy has not ceased its action. Rather there is an action for fascism revival through building of memorial things for fascism leaders who are war criminals. On the other hand, Italy has not yet made adequate reparation either in the form of compensation and satisfaction.

With regard to termination of an internationally wrong full act, there is an indirect continuity of Italy's action. An open display of fascist symbols, values, leaders, war criminals, and such public support for fascism itself are manifestation of resurgence or revival of fascism which are evident in the present day of Italy. One critical example of such resurgence of fascism was "the building and opening of the Graziani monument" in Affile, 50 miles East of Rome. On August 11, 2012 a ceremony was held in the presence of Italian dignitaries and a Vatican representative during which a memorial was opened covered in the Italian flag to "honor" Rodolfo Graziani, a war criminal during the Italo-Ethiopia war and five year occupation.

According to BBC news, the mausoleum in Affile cost 127,000 euros (£100,000; \$157,000) (BBC, 15 August 2012). According to Mayor Ercole Viri, the memorial has national-wide significance as it aimed at dismissing criticism as "idle chatter". The Mayor is blessing the action of fascism as good things. The people of the village also memorized Graziani as one of the village's "famous sons", "Fatherland", and "Honour". It is obvious that it is due to his honour that they dedicated him with a mausoleum and memorial park. The existence of pro-fascism and advocators of inhumane action of fascism against Ethiopia is also assured when I communicate three Italian visitors of Ametsegna Washa in February 2018. In my February 2017 conversation with Luther, a Germany Italian visitor of Ametsegna Washa, he told me that there are peoples in Italy who congratulate fascism ${ }^{4}$. One year later, three Italian visitors namely David, Marco, and Franco told me that "we want to make a video, documentary film, about the cave to expose the inhumane action of fascism in Ethiopia" so as to persuade those individuals and institution in Italy who viewed the presence of Italy in Ethiopia as good thing ${ }^{5}$. This all shows the continuity of fascism among the generation. Memorizing war criminals is also wrongful act at international level.

In history building a memorial mausoleum and park for war criminal, military commander in colonial wars, for an individual who carried out massacres and used chemical weapons is however uncommon. Nevertheless, Italy has dedicated a park and a museum to the fascist general and Minister Rodolfo Graziani who is a war criminal responsible for the genocide of February Addis Ababa massacre. In 1937, he directed a massacre, also known as yeyekatit chifchefa, Grazianin Massacre, of over 30,000 unarmed civilians in Addis Ababa massacred. Over 440 monks were murdered. People viewed him as "Butcher of Libya" as well as Butcher of Ethiopia. Sadly, Italy is now in a path of rehabilitating war criminals.

This foreshadows the incessant of fascism in Italy. Italy's action is still continued. Therefore, there is a need to apply for UN, EU, and Italy government so as to push them to stop the action of memorizing war criminals and to pay appropriate and adequate reparation either in the form of restitution, compensation, and apology.

Not only Italy's action remains un-ceased, there is no adequate restitution. Italy had paid only six million sterling pounds in 1947 which was used to build Koka hydro power. This is a miniscule compensation which is

\footnotetext{
${ }^{4}$ Personal communication with Luther, February 2017.

${ }^{5}$ Personal communication with Marco, February 2018.
} 
not even comparable with the huge internationally wrongful act. This is illogical, irrational, inadequate, and inappropriate restitution. Comparatively, Italy had agreed to pay US\$125 million to Yugoslavia, US\$105 million to Greece, \$100 million to Soviet Union, and recently \$5 billion to Libya (Alemayehu, 2017). The Libyan case is both a paradox, enigmatic, and also good news for Ethiopia which is a recent agreement made between Libya and Italy. What makes it enigmatic is $\$ 5$ billion compensation to Libya as restitution is because of Italy colonization and the deployment of 20,000 Libyans in the Fascist aggression on Ethiopia. The other paradox is that Libyan askari also committed war crimes against Ethiopia as they had been serving as soldiers of fascism. Thus, Libyan soldiers had been collaborator of fascism; the payment seems a payment for their support in the war against Ethiopia rather than a reparation in a real sense.

With regard to Ethiopia, the only restitution that has happened up to now was the return of Axum Obelisk to Ethiopia. All other properties looted are not yet returned to Ethiopia which is now possessed by Italy and Vatican including the king's airplane "Tsehay" which is found at the Italian air force museum and over 500 manuscripts in Vatican library (Alemayehu, 2017). Therefore, there is an urgent a need for requesting adequate and appropriate restitution. This can be directed for UNSC, EW, and Italy government. There is also a need of collaboration among Ethiopia Diaspora in alarming the Ethiopian government.

Finally, so far, there is no apology from the Vatican to Ethiopia. There is a need of Vatican apology for its support and backing of the 1935-41 occupation of Ethiopia by Fascist Italy. Italy invaded Ethiopia through weapons blessed by the Vatican's Pope Pius XI. Even the pope ordered that the war against Ethiopia should be considered as "a holy war", because "it is a war against a country of infidels and schismatic, to the expansion of the Catholic Faith”. The pope also played a significant role in mobilizing public support for fascist invasion of Ethiopia both internally and externally.

There is a need of Vatican apology for the sake of justices and principle of international consistency. The Vatican has willingly expressed its apology for Jews for its irrationalities and complexity with the Perpetrator, Nazis. For this "His Holiness Pope Benedict XVI" confirmed that the genocide committed against the Jews was an "unimaginable crime" (Alemayehu, n.d.). Differently, such apology has been non-existence to Ethiopian. This is against the back drop of principle of international law. Vatican must be consistent for its international action and reaction. The apology extended for Jews must be expressed for Ethiopia.

Finally, Italy had used chemical weapons of which mustard gas is at different battles and areas. The mustard gas massacre of the inhabitant of Menz, Merhabite, Jamma, and Jiru at Ametsegna Washa is different in terms of severity, usage, and intensity. It is one of the single-most grave genocide committed by Italy in Ethiopia. 5,000 people lost their life inside the cave as a result of the mustard gas. Very huge yet not confirmed number of peoples becomes victim of the gas. The survivor of the catastrophic genocide in the cave were also tortured, inhumanely killed, slathered to lolberet cliff, and machine gunned. This is the first-ever huge massacre committed by Italy. For this exceptional war crime Italy has not yet made apology and appropriate restitution. Adding insult to the injury, Italy is building memorial museum and parks for war criminal which is illegal, irrational, immoral, and illogical. Thus, there is a need on the part of Ethiopians to document the Ametsegna Washa massacre, the forgotten and undocumented massacre, and exposed it then after requesting Italy for "National apology and adequate reparation".

In this regard, there is a growing sentiment national-wide among the generation regarding the imperative of the apology and reparation. For instance, Daniel Jote Mesfin, head of the Ethiopian Patriots' Association stressed the need of apology and reparation which can be read as "Italy should issue an apology and 
compensate Ethiopia for all of its war crimes, in particular for the chemical attack against Ethiopians” (Tamene, 2015). There is also good effort by the Ethiopian Patriots Association and Global Alliance for Justice-The Ethiopian Cause in appealing the need of apology and reparation to the concerned bodies. Workineh Tegegne, Vice president of the Ethiopian Patriots Association confirmed to Reuters about the sending of appeal of the UNSG to force the current Italian government to pay the amount demanded by Emperor Haile Selassie which is \$600 million (Tadesse, 2014).

Generally, by documenting and revealing the massacre it is imperative to request apology and reparation. This can be possible through Ethiopian government appeal to the UNSC. Along this, collecting petition and submitting it for Italy embassy in Ethiopia, EU, AU, and other concerned bodies has paramount importance. Along this, preserving the cave is a required think. The concerned individuals and government bodies should work together to preserve the cave and thereby memorizing our fathers.

\section{Concluding Remarks}

This study attempted to analyze mustard gas massacre by Italy in 1939 against the inhabitant of Menz, Jamma, Merhabete and Jiru in Ametsegna Washa. The study revealed that more than 5,500 peoples died due to the massacre. Along this, unknown number of cattle, goats, and sheep were died. When we see the health effect of mustard gas, those who survived faced respiratory system problem, skin related problem and most of them were blind. It has also unconfirmed environmental effect. Mustard gas massacre also causes moral and psychological damage. The surrounding fertile land is not yet cultivated because the land is viewed as "land of blood". The cave also viewed as "cave of devil”. The survival of the catastrophic massacre had faced physical injury which includes blindness, skin related problem, respiratory problem and as a result they had lived their remaining age with misery.

In this regard Italy had committed all elements of crime particularly genocide, crime against humanity and war crime. Along this, Italy had used internationally prohibited mustard gas by violating international customary laws and the Geneva Protocol. In view of that, Italy had committed international wrongful acts for which Italy should take responsibility. Sadly, Italy had not yet fulfilled its responsibility under international law. On the one hand, Italy has not ceased its action. Rather there is an action for fascism revival through building of memorial things for fascism leaders who are war criminals. On the other hand, Italy has not yet made adequate reparation either in the form of compensation and satisfaction.

This study, therefore, calls for:

- Coordinated appeal for UNSC, EU, current Italy government for apology and adequate war reparation.

- All people should strive for the ensuring justice for Ametsegna Washa in particular and Ethiopia in general.

- The Ethiopian Patriotic Association, the media, and other concerned institutions should take the lion share in ensuring justice for Ametsegna Washa massacre and Ethiopia in general.

- Vatican apology must be extended to Ethiopia.

- Along this, the study calls for further archeological and social anthropological study in the cave.

- Finally, conserving the cave is mandatory task of the generation. The place is not well-protected and, therefore, the government as well as the other concerning bodies should give serious attention in preserving and memorizing the historical cave. 


\section{References}

Alemayehu, K. (2017). My journey with The United Nations and quest for Africa's unity and justice for Ethiopia. USA: Dorrance Publishing.

Alemayehu, K. (n.d.). When will the Vatican apologize to Ethiopia? Retrieved from http://www.globalallianceforethiopia.org/files/VATICAN_APOLOGY_TO_ETHIOPIA.pdf

BBC. (15 August 2012). Italy memorial to Fascist hero Graziani sparks row. Retrieved April 2018 from http://www.bbc.com/news/world-europe-19267099

Berg, B. L. (2001). Qualitative research methods for the social sciences (4th Ed.). USA: Allyn \& Bacon.

Brophy, L. P., \& Fisher, G. B. (1959). United States Army World War II. The technical services: The chemical warfare service: Organizing for war. Washington, D.C.: Center of Military History United States Army.

Bryman, A. (2012). Social research methods (4th Ed.). Oxford: Oxford University Press.

Creswell, J. (2009). Research design: Qualitative, quantitative, and mixed methods approaches (3rd Ed.). California: SAGE Publications.

Fitzgerald, G. J. (2008). Chemical warfare and medical response during World War I. Am J Public Health, 98(4), 611-625.

Global alliance for justice-The Ethiopian cause. (2015). Regarding the fascist war crimes during 1935-41. Retrieved January 2018 from http://www.africanidea.org/International_Conference_Objectives_Program.pdf

González-Ruibal, A., Sahle, Y., Ayán Vila, X. (2011). A social archaeology of colonial war in Ethiopia. World Archaeology, 43(1), 40- 65.

Grip, L., \& Hart, J. (2009). The use of chemical weapons in the 1935-36 Italo-Ethiopian War. SIPRI Arms Control and Non-proliferation Programmme, October 2009.

Kothari, C. R. (2004). Research methodology: Methods and techniques (2nd Ed.). Sciences (4th Ed.). USA: Allyn \& Bacon.

Kreppel, H., Kehe, K., Balszuweit, F., Emmler, J., Jochum, M., \& Thiermann, H. (n.d.). Sulfur mustard research—Strategies for the development of improved medical therapy. Journal of Plastic Surgery, 18, 312-332.

Paige, C. R. (2009). Canada and chemical warfare 1939-1945 (Unpublished Master Thesis, Saskatoon: University of Saskatchewan).

Szinicz, L. (2005). History of chemical and biological warfare agents. Toxicology, 214(3), 167-181.

Tadesse, T. (August 20, 2014). Ethiopia ex-fighters demand Italian compensation. The Independent News. Retrieved April 2018 from https://www.theindependent.co.zw/2004/08/20/ethiopian-ex-fighters-demand-italian-compensation/

Tamene, A. (2015). Ethiopia veterans want Italy apology, compensation. The Anadolu Agency News. Retrieved April 2018 from https://aa.com.tr/en/world/ethiopia-veterans-want-italy-apology-compensation/50348

U.S. State Department. (n.d.). Protocol for the prohibition of the use in war of asphyxiating, poisonous or other gases, and of bacteriological methods of warfare (Geneva Protocol). Retrieved from https://www.state.gov/t/isn/4784.htm\#treaty

United Nations. (2005). Responsibility of states for internationally wrongful acts 2001. Retrieved from https://www.law.umich.edu/facultyhome/drwcasebook/Documents/Documents/International\%20Law\%20Commission\%202 001\%20Draft\%20Articles\%20on\%20State\%20Responsibility.pdf

Zewude, B. (2002). A history of modern Ethiopia. Addis Ababa: Addis Ababa University Press. 
Appendix A: Archeological Evidences Found in the Cave (Photo by Gashaw Ayferam in Feburary 2017 and March 2018)

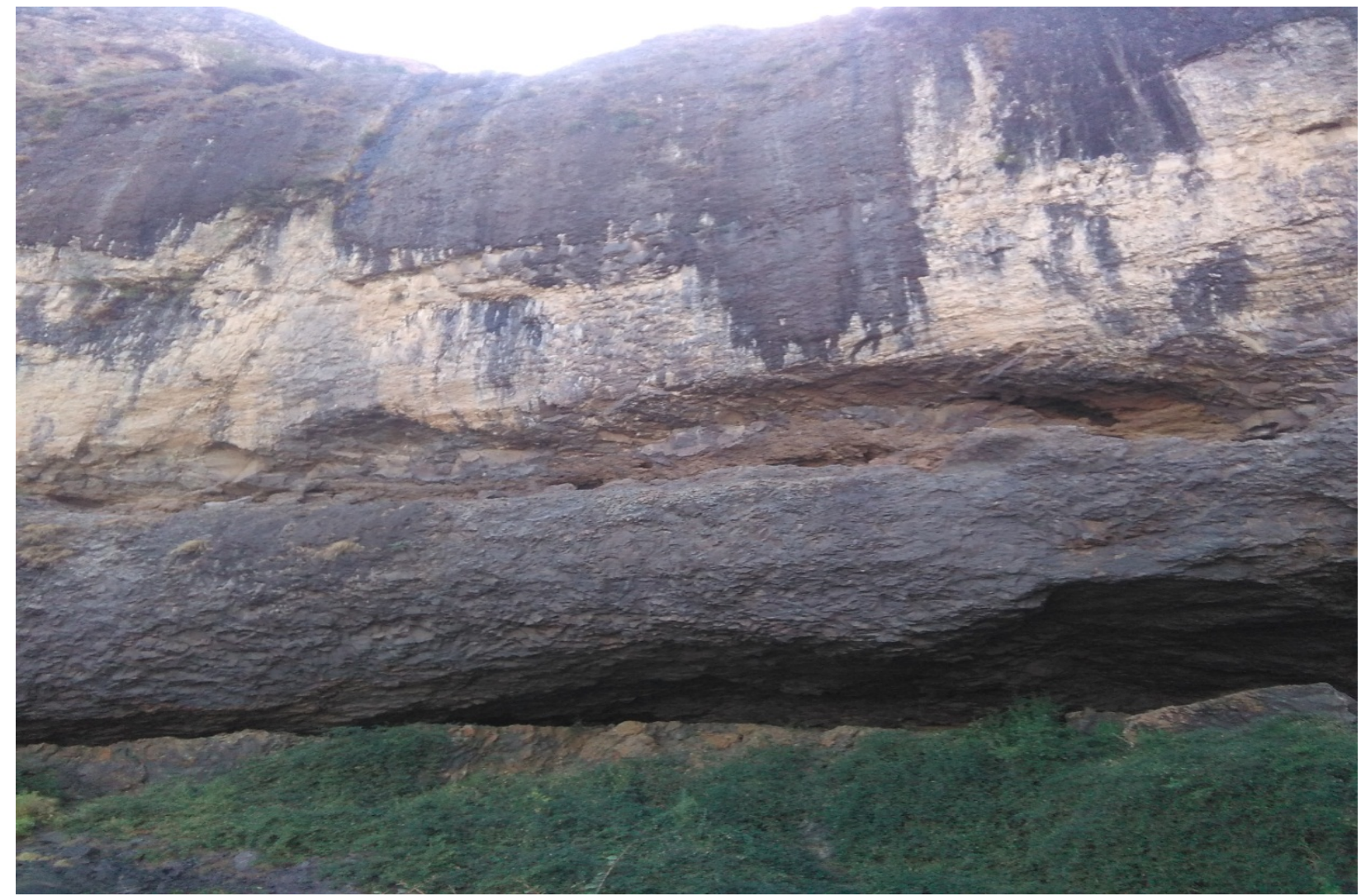

Figure 1. Entrance of the cave and the second high cliff called Gedam.

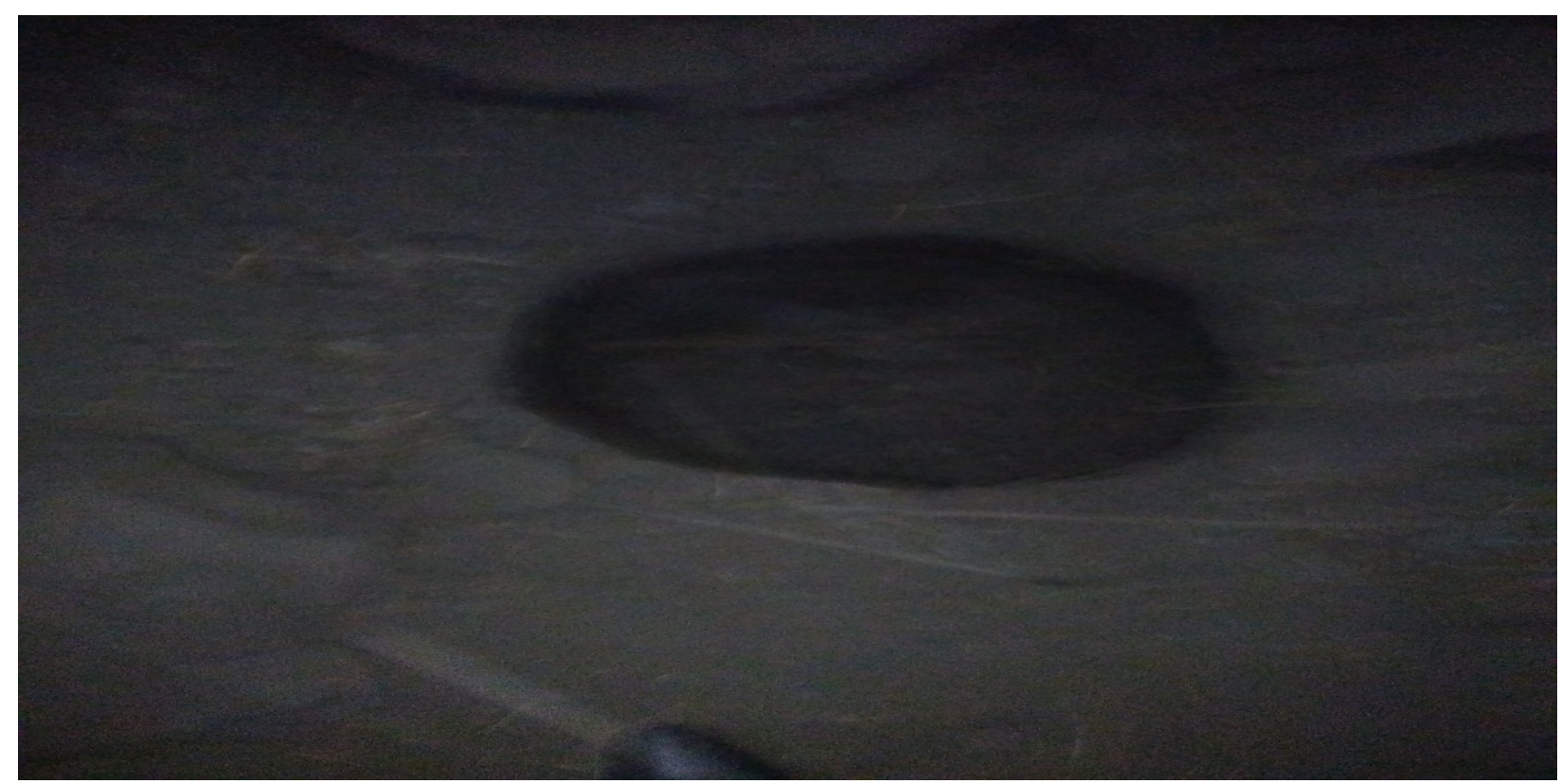

Figure 2. Underground cereal basket. 


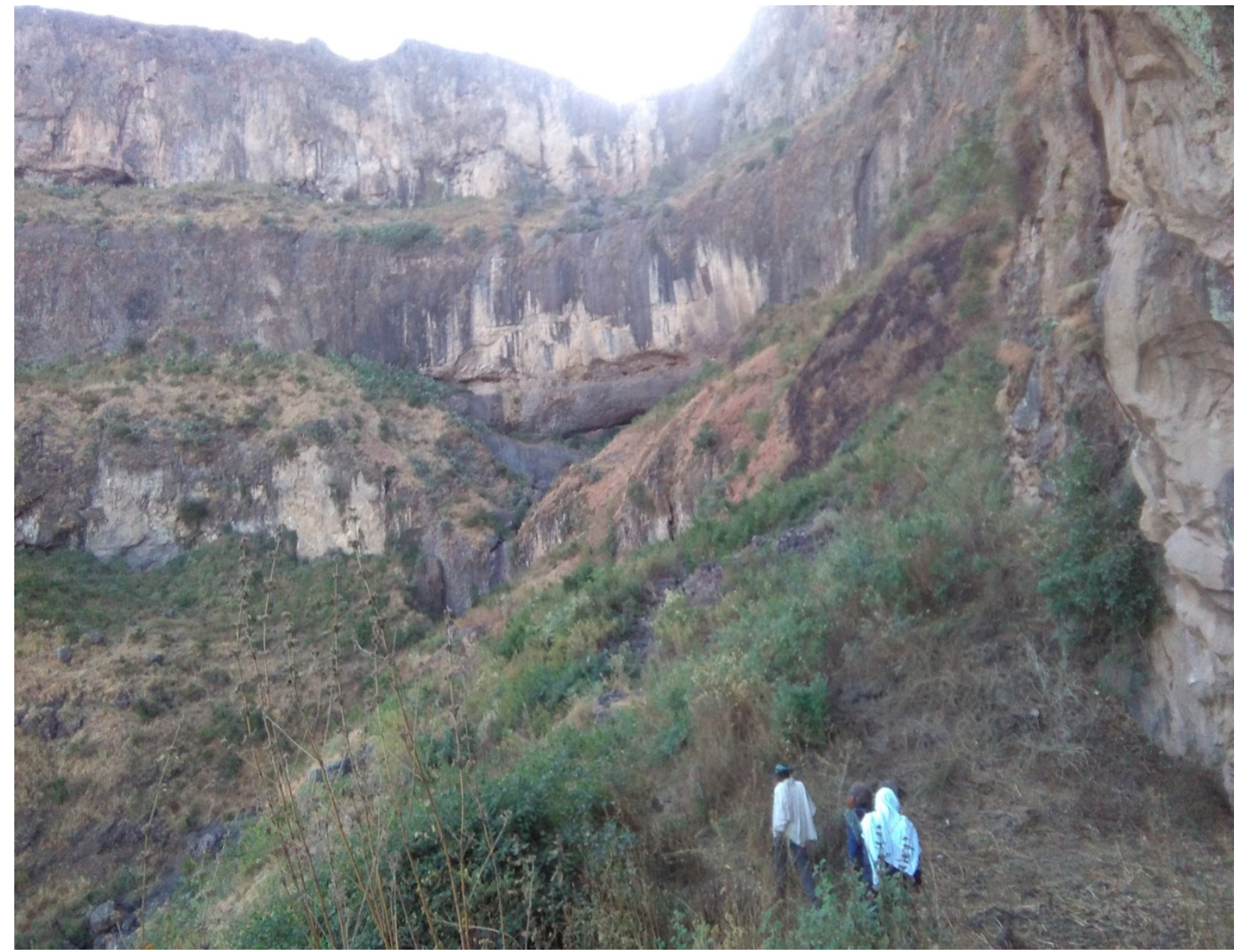

Figure 3. Geographical view of the cave. 


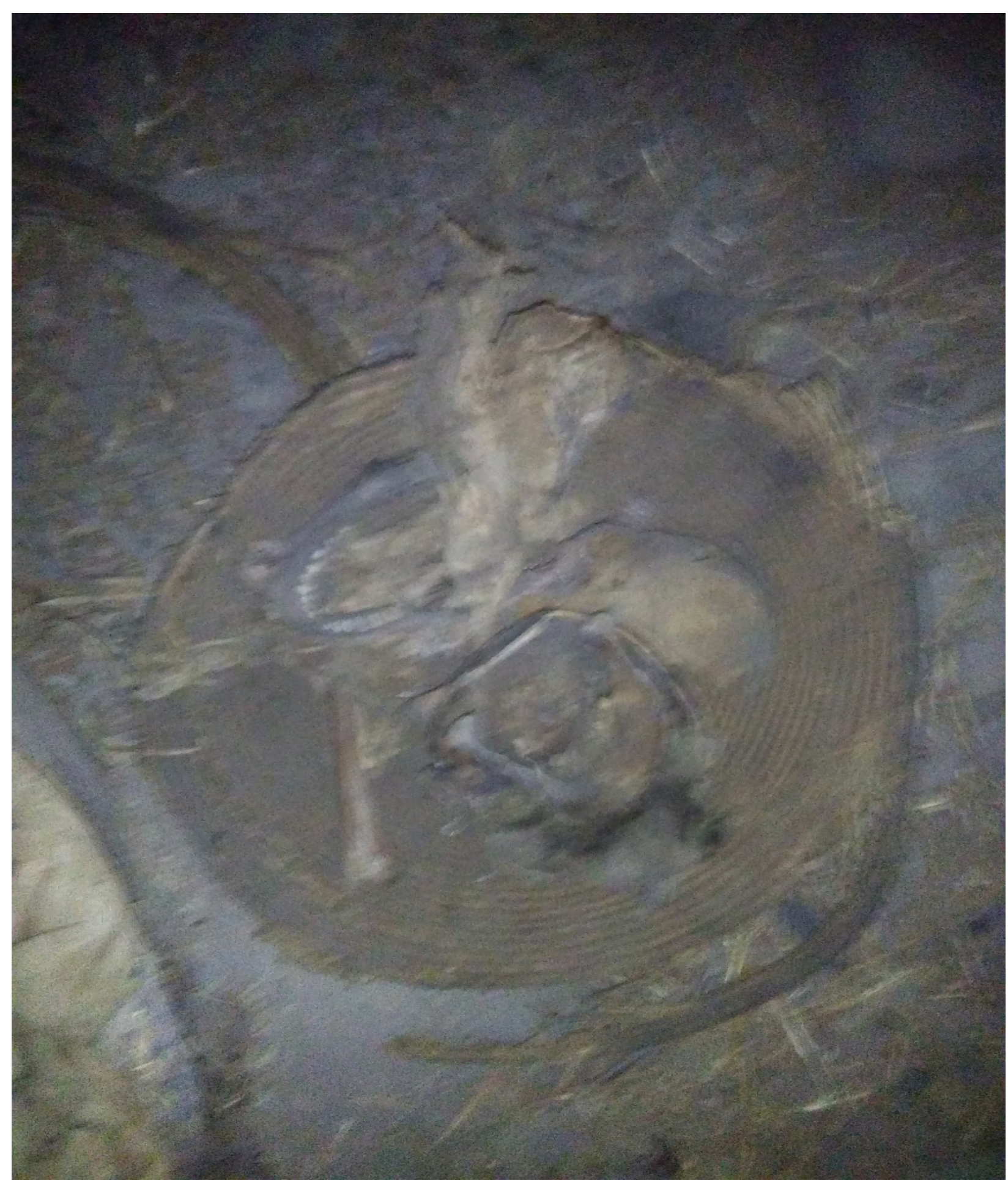

Figure 4. Human bodies and Enkib. 

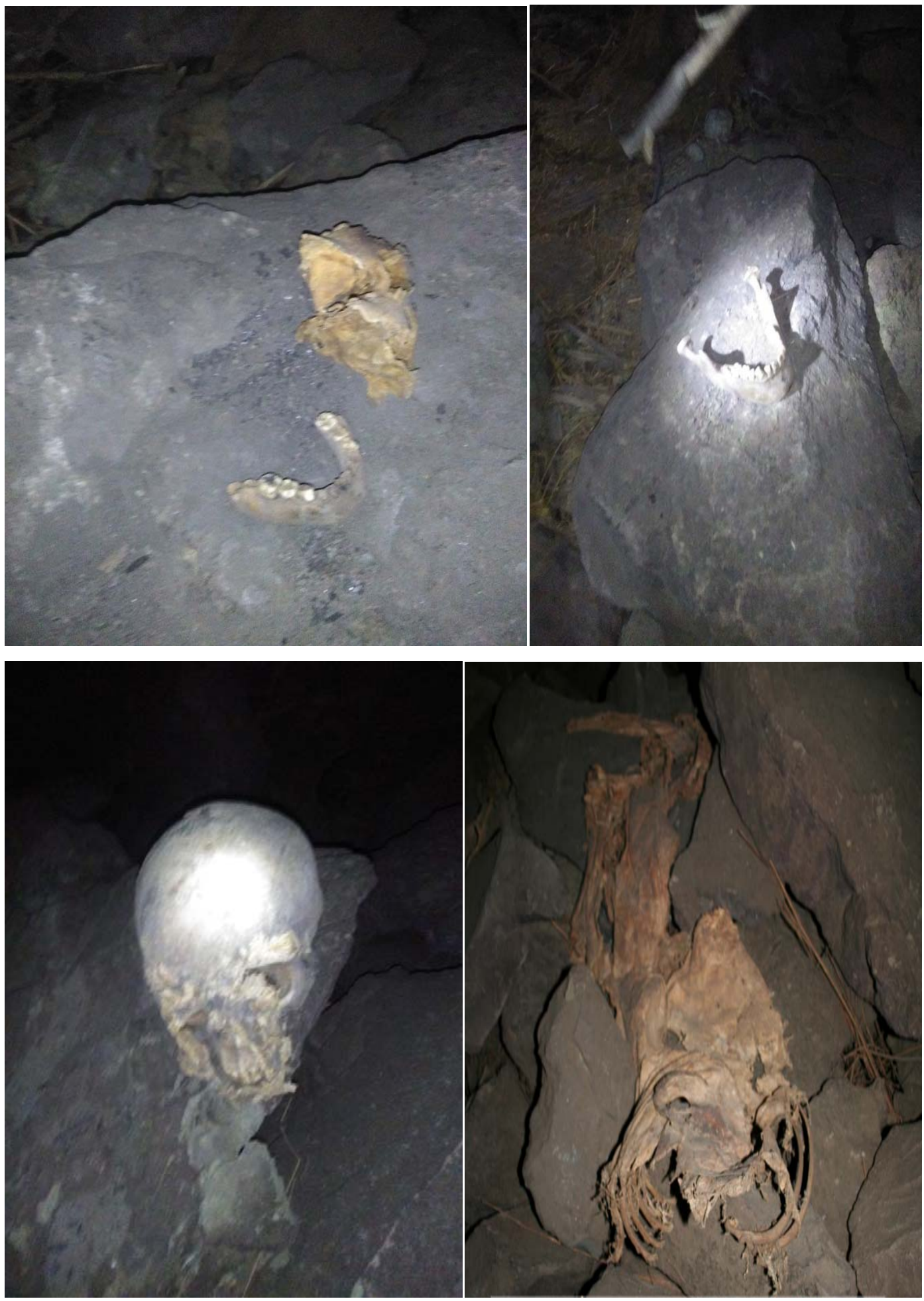

Figure 5. Human remains inside the cave. 

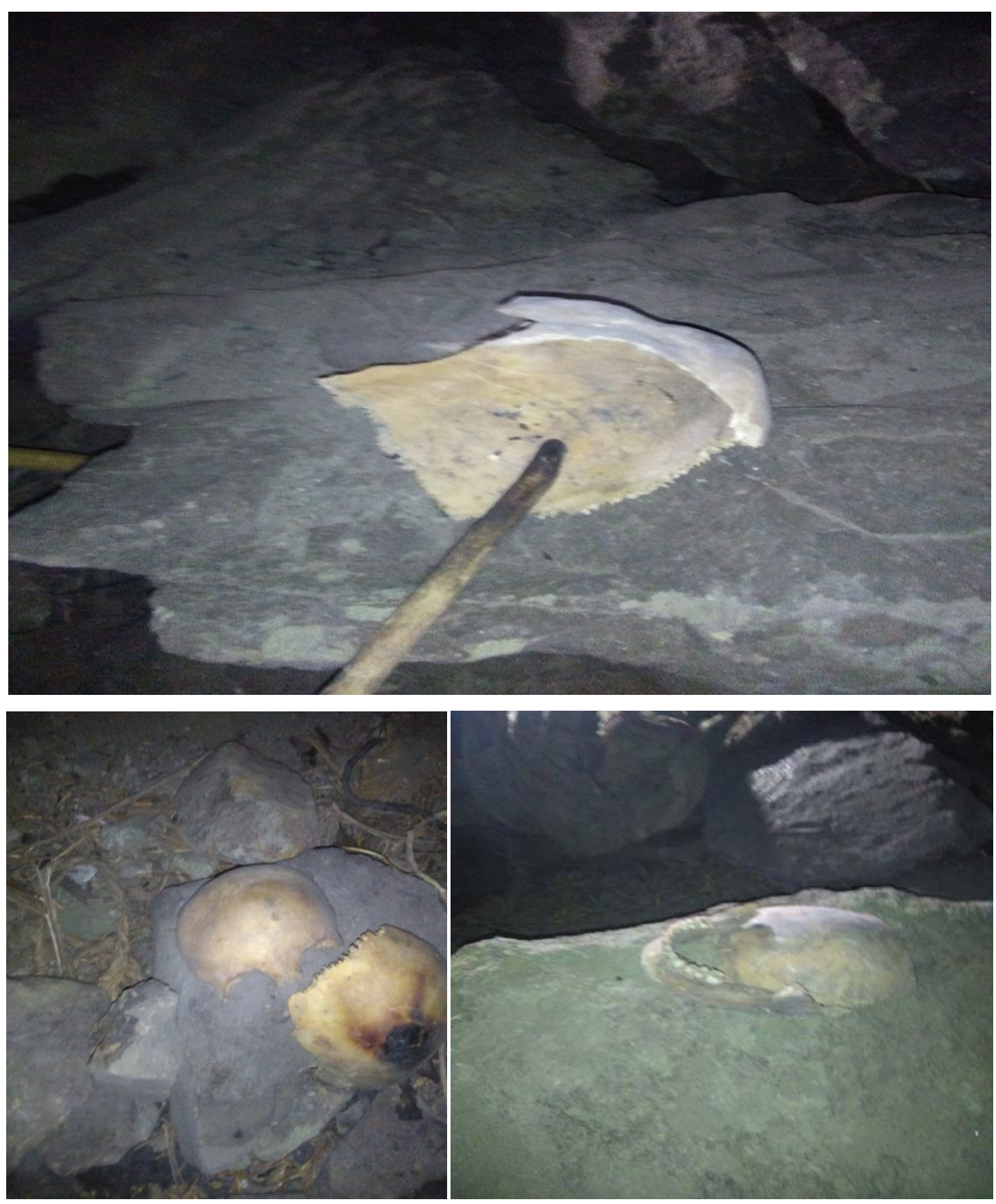

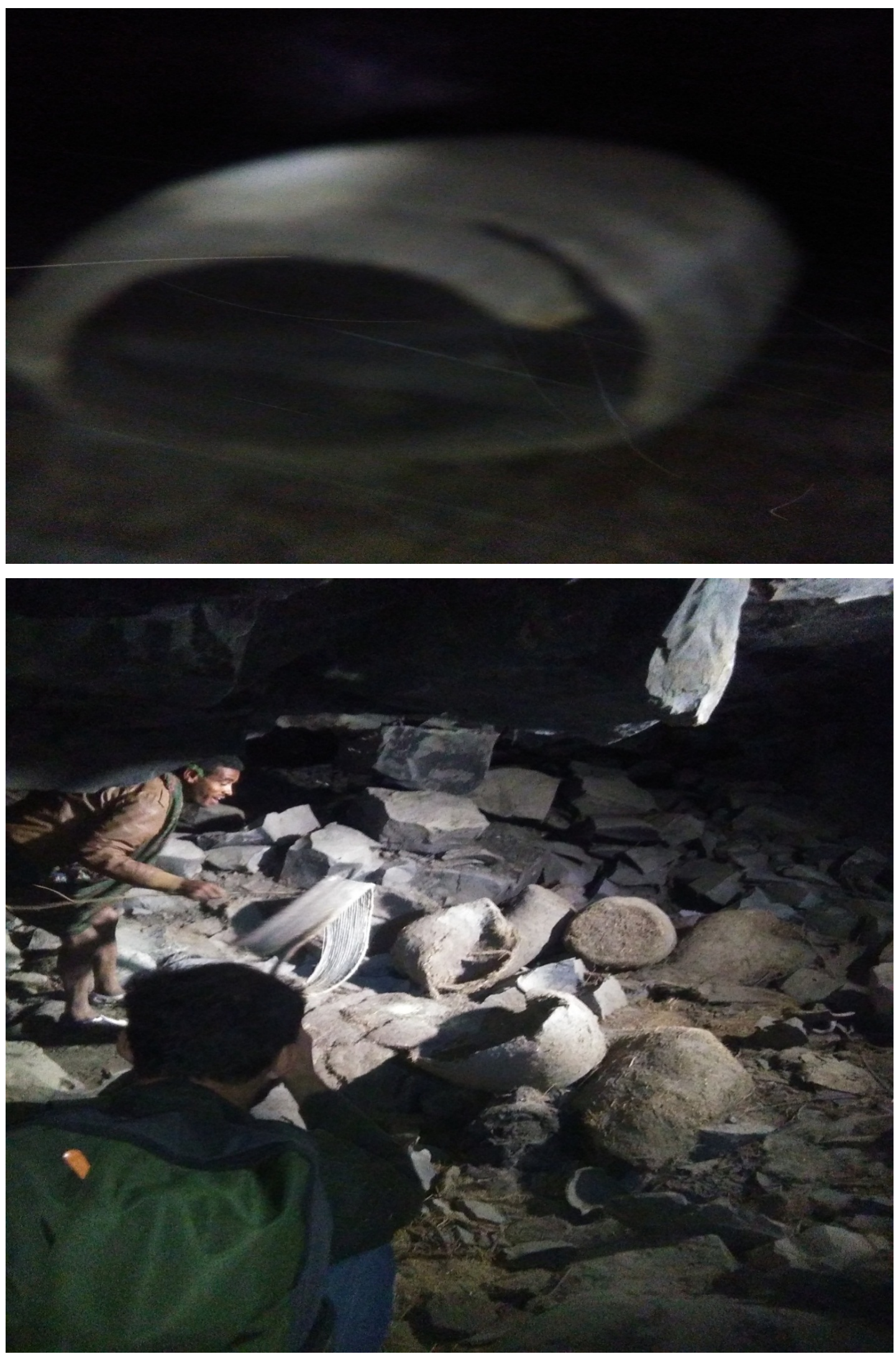

Figure 6. Dibgignet/cereal basket. 

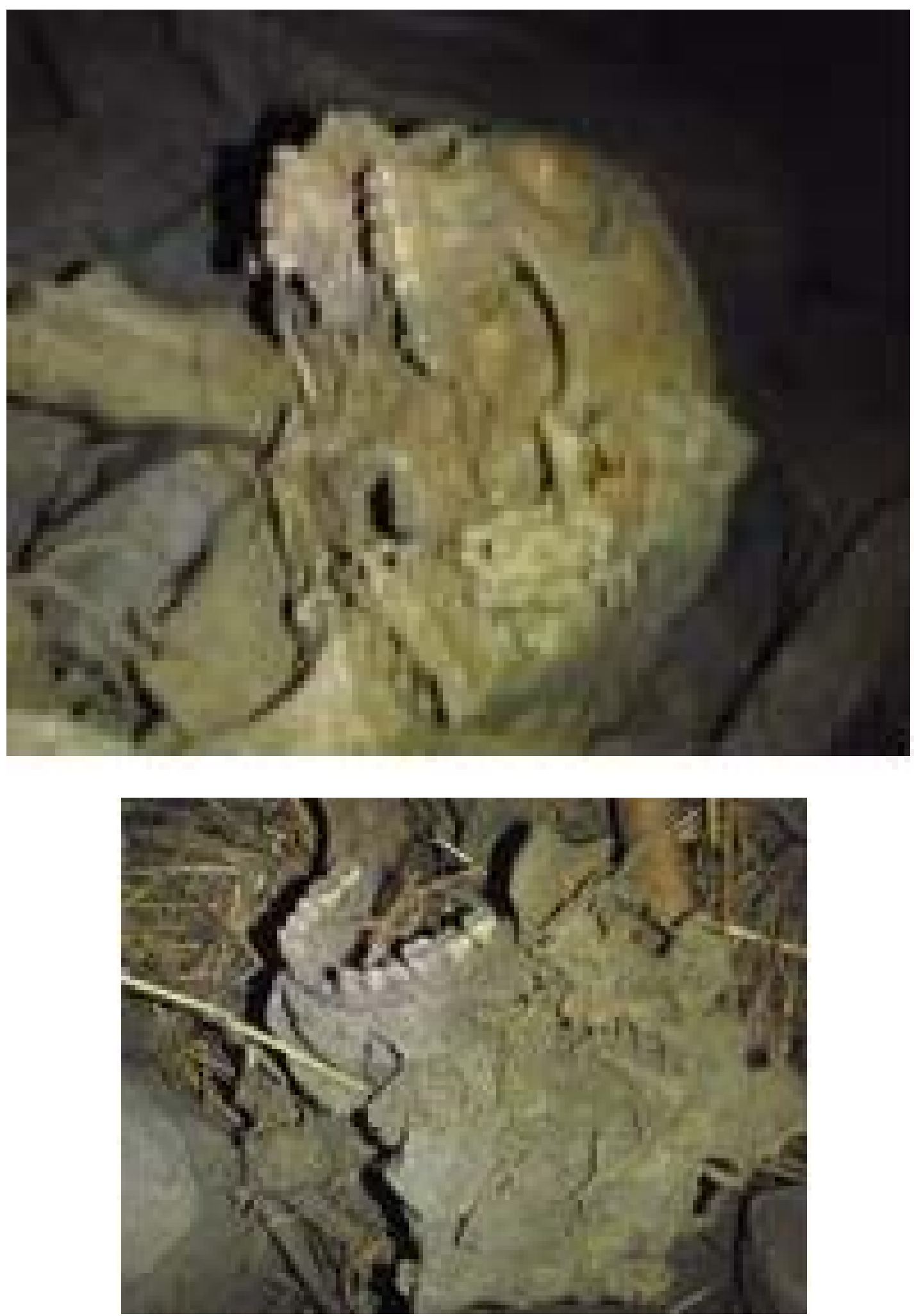

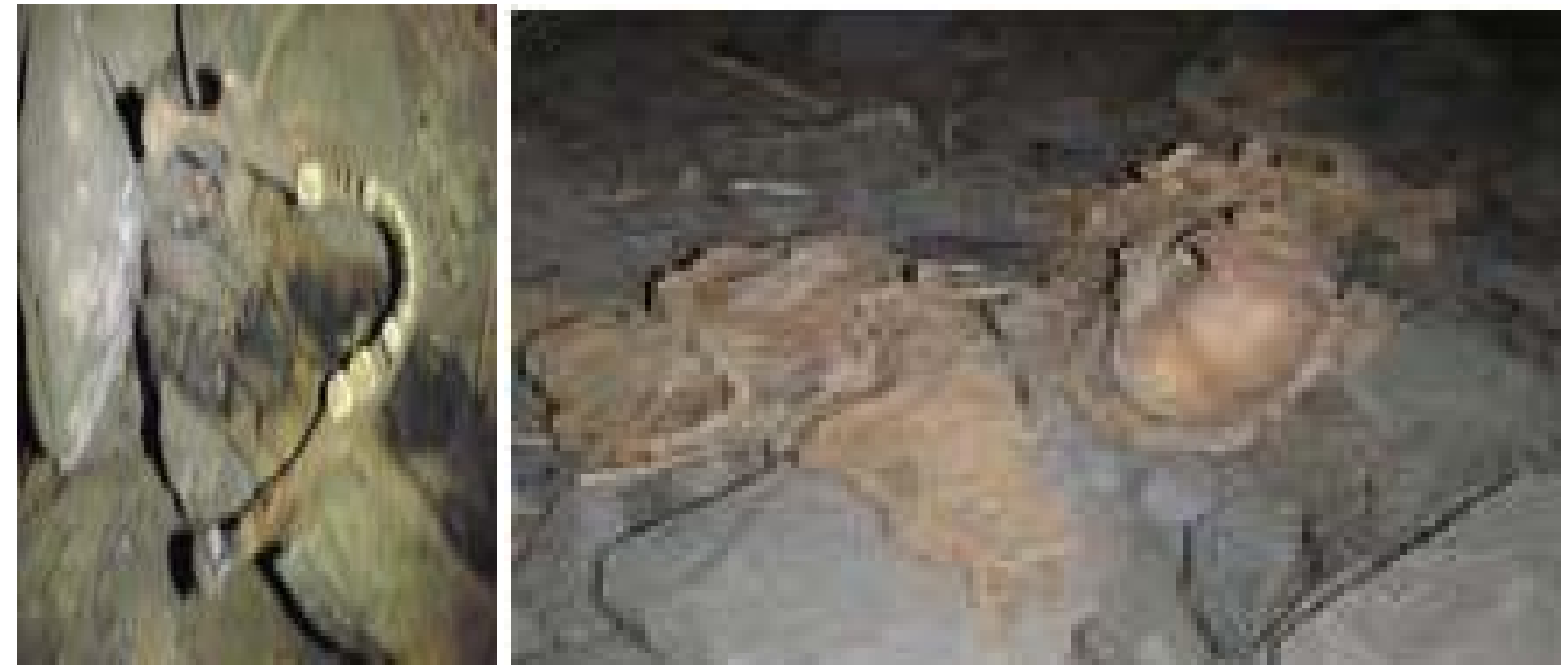

Figure 7. A human body remains inside the cave.

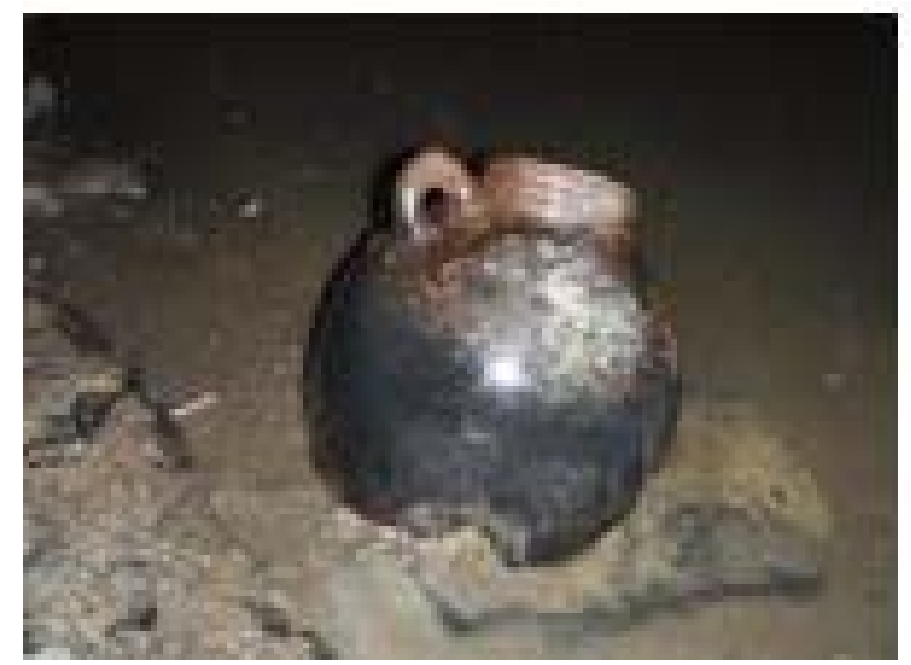

Figure 8. Ensira. 


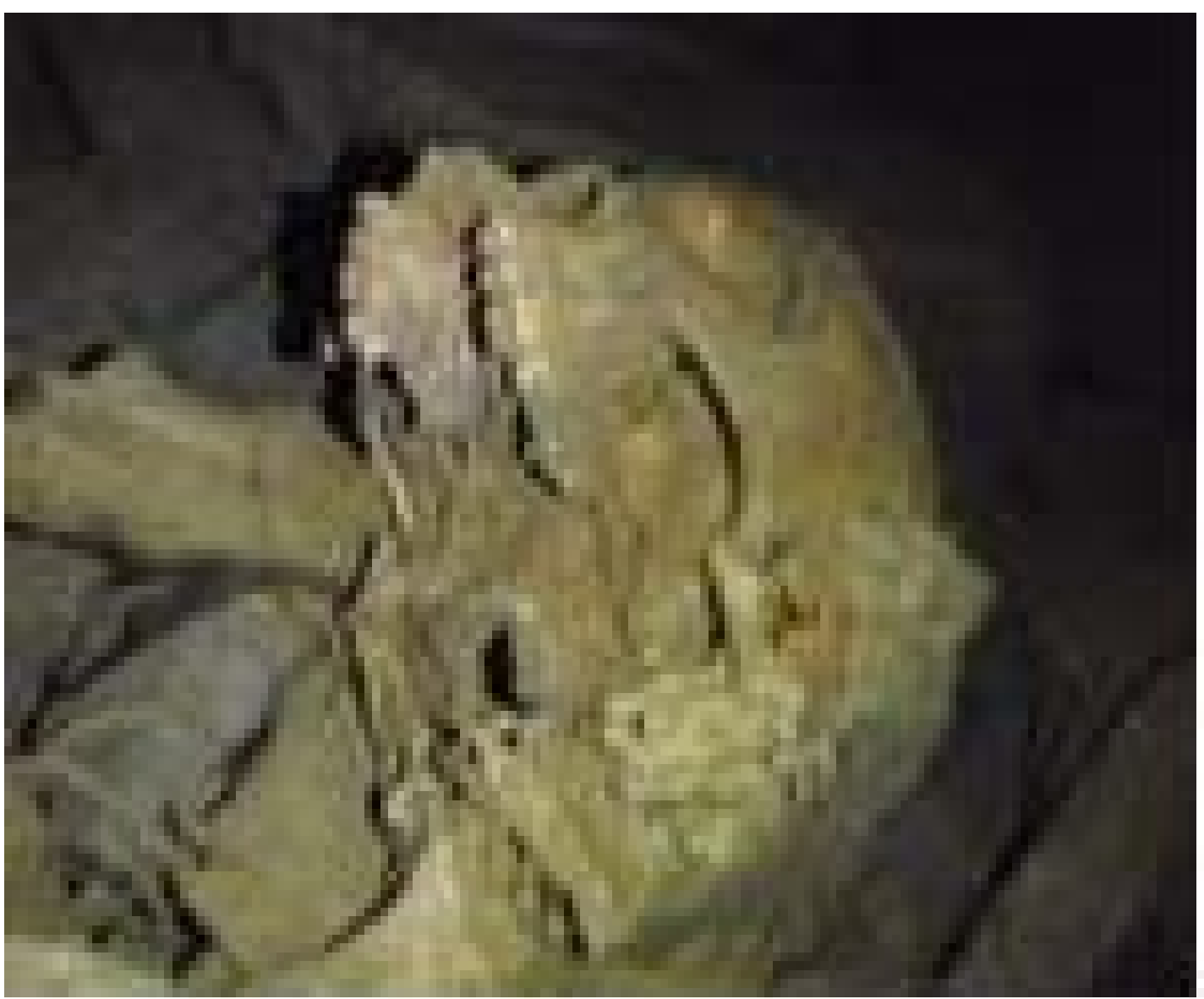




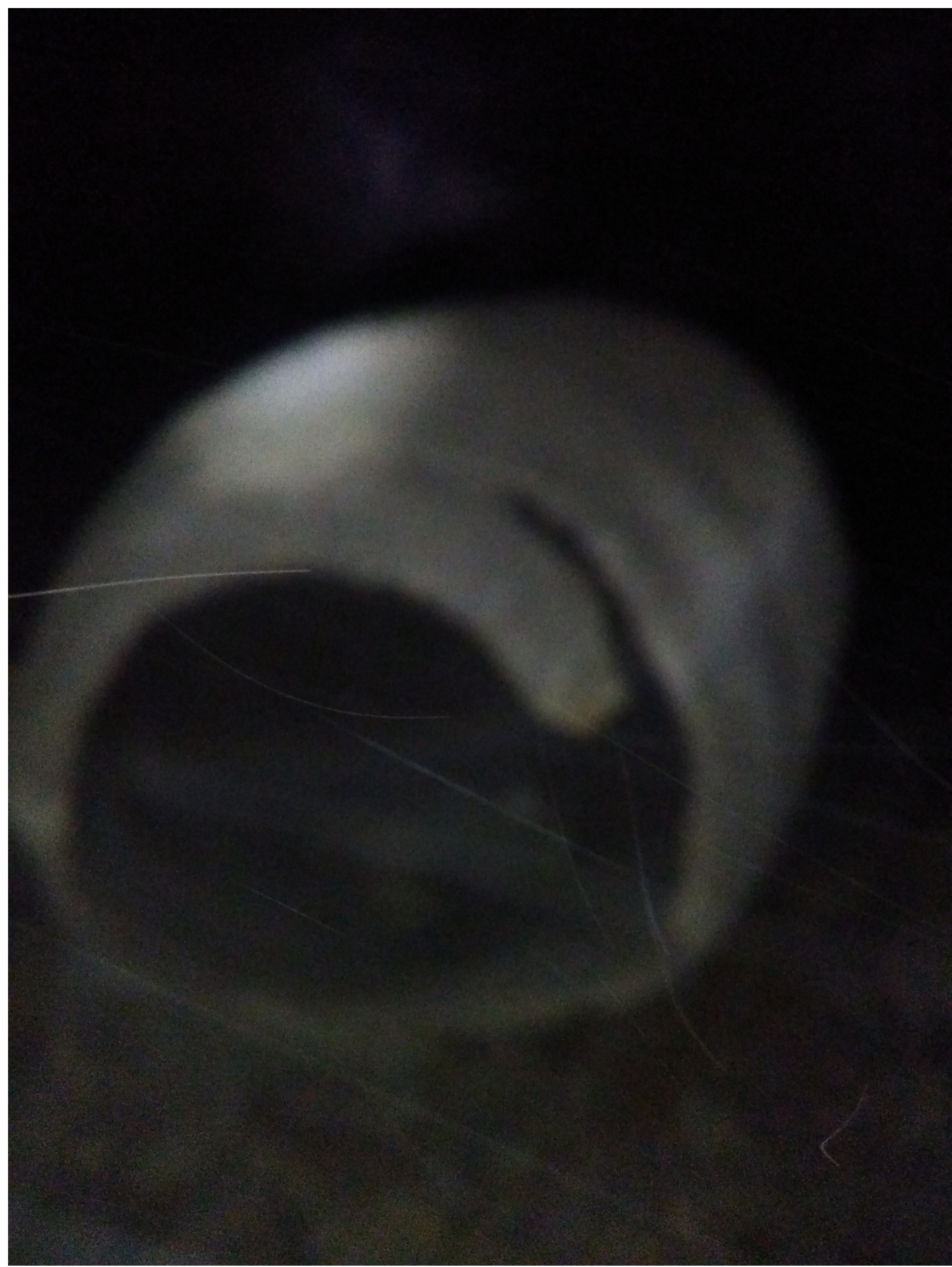




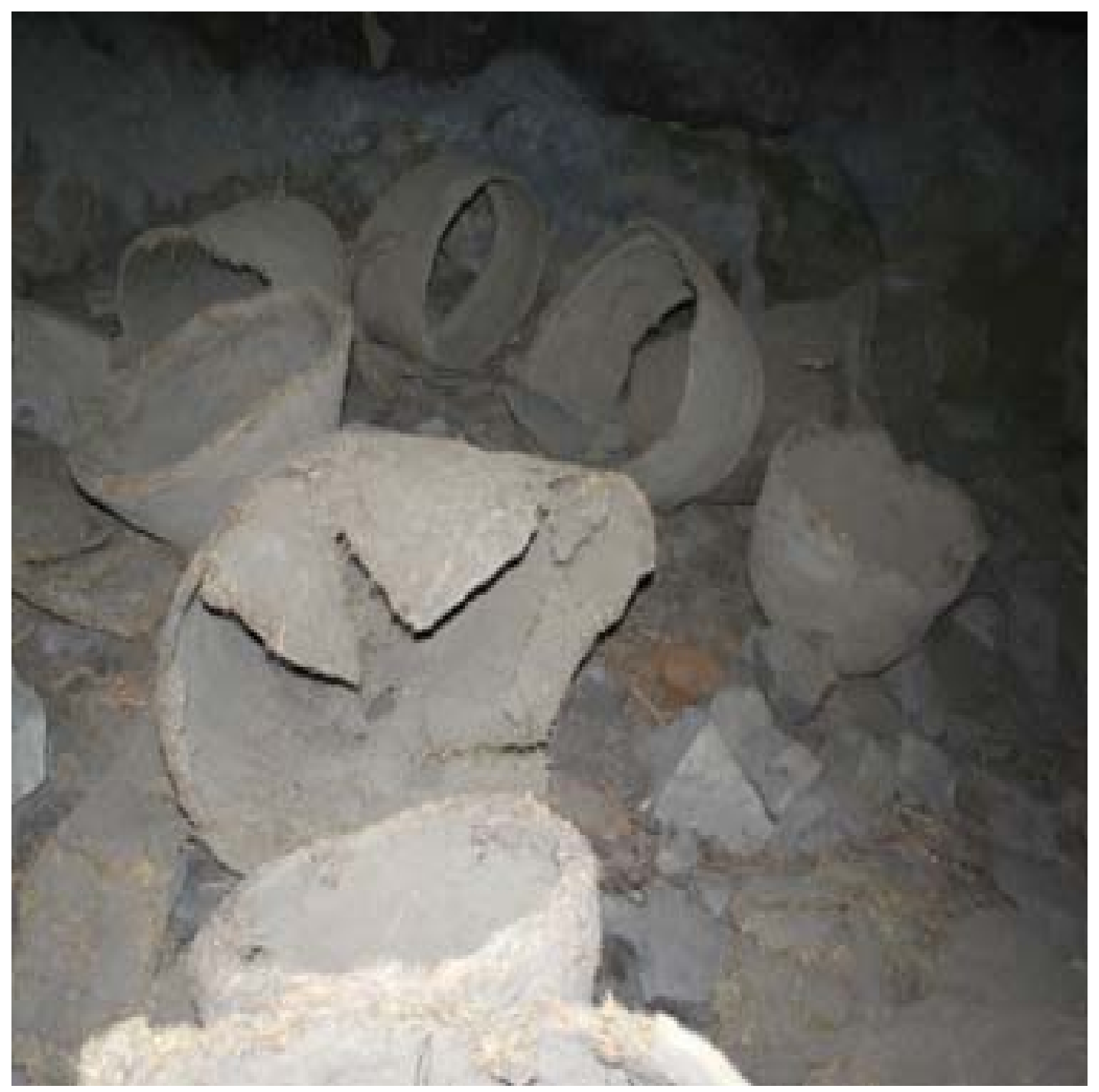




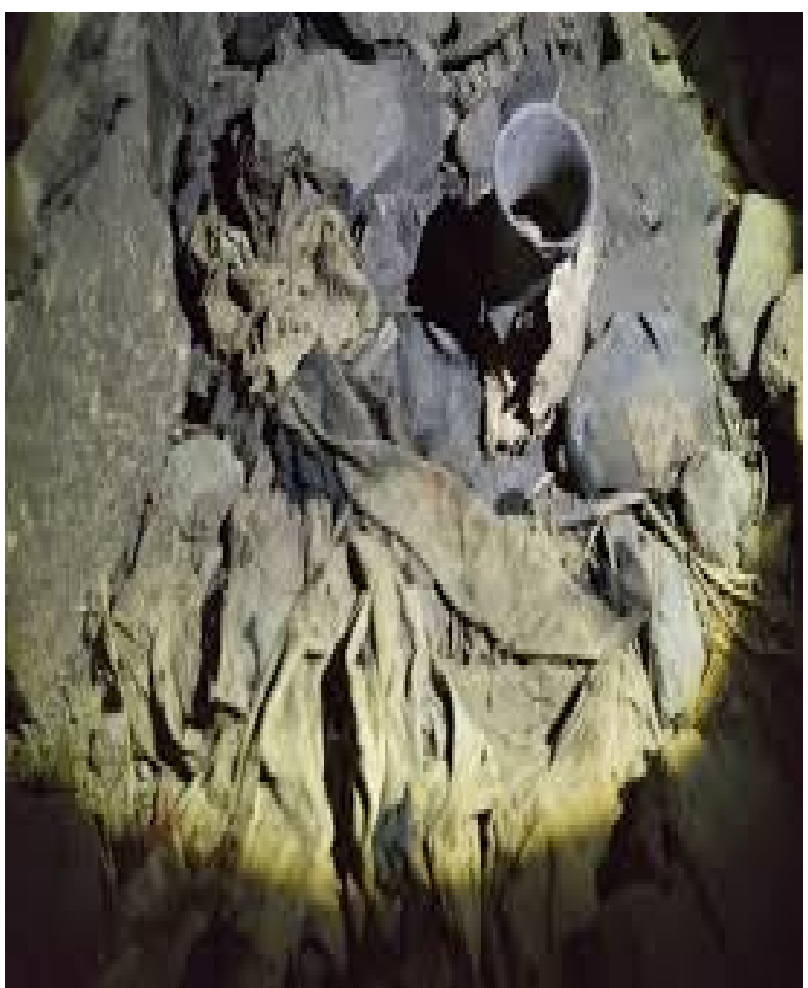




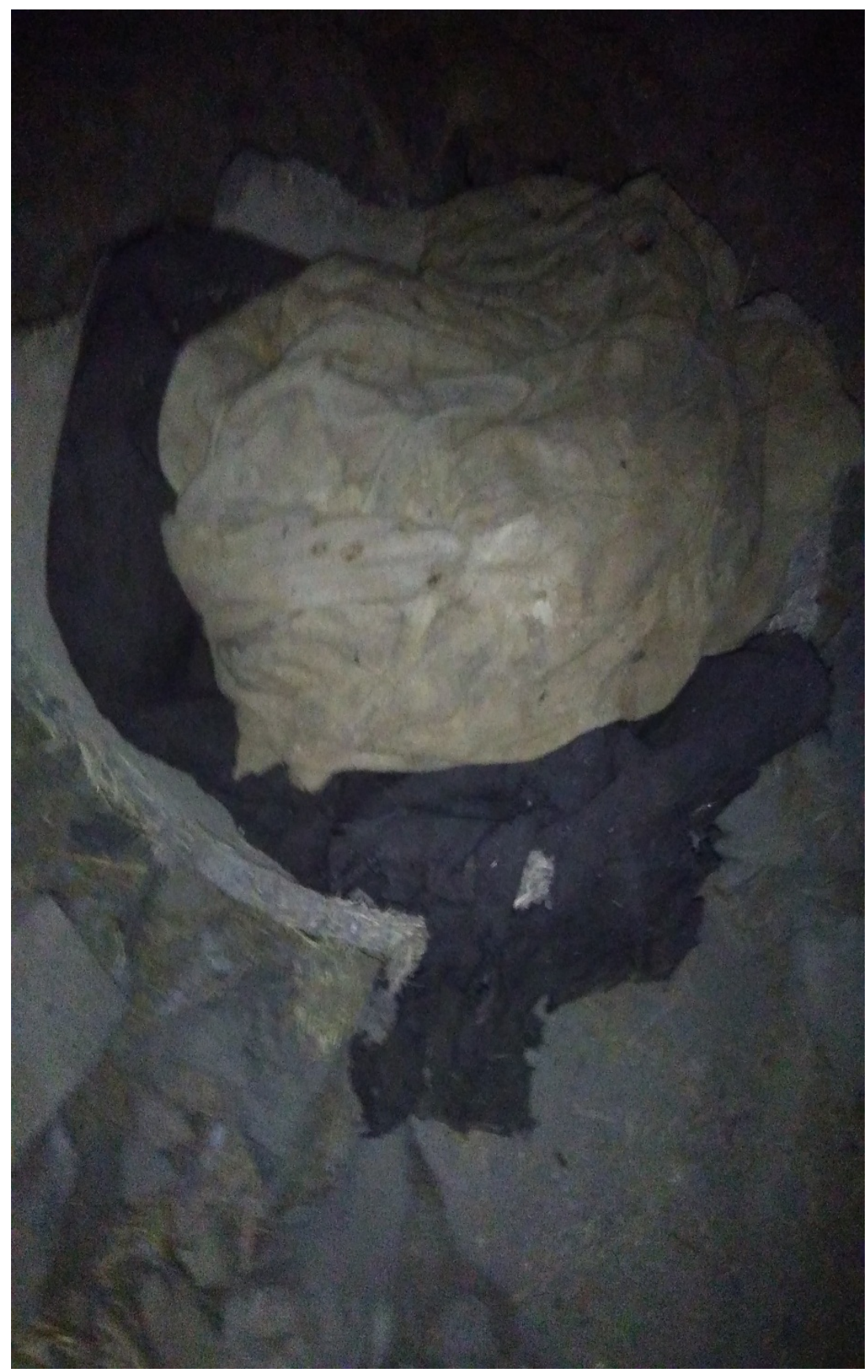

Figure 9. Cloths made up of cotton and Tikur Shashi. 


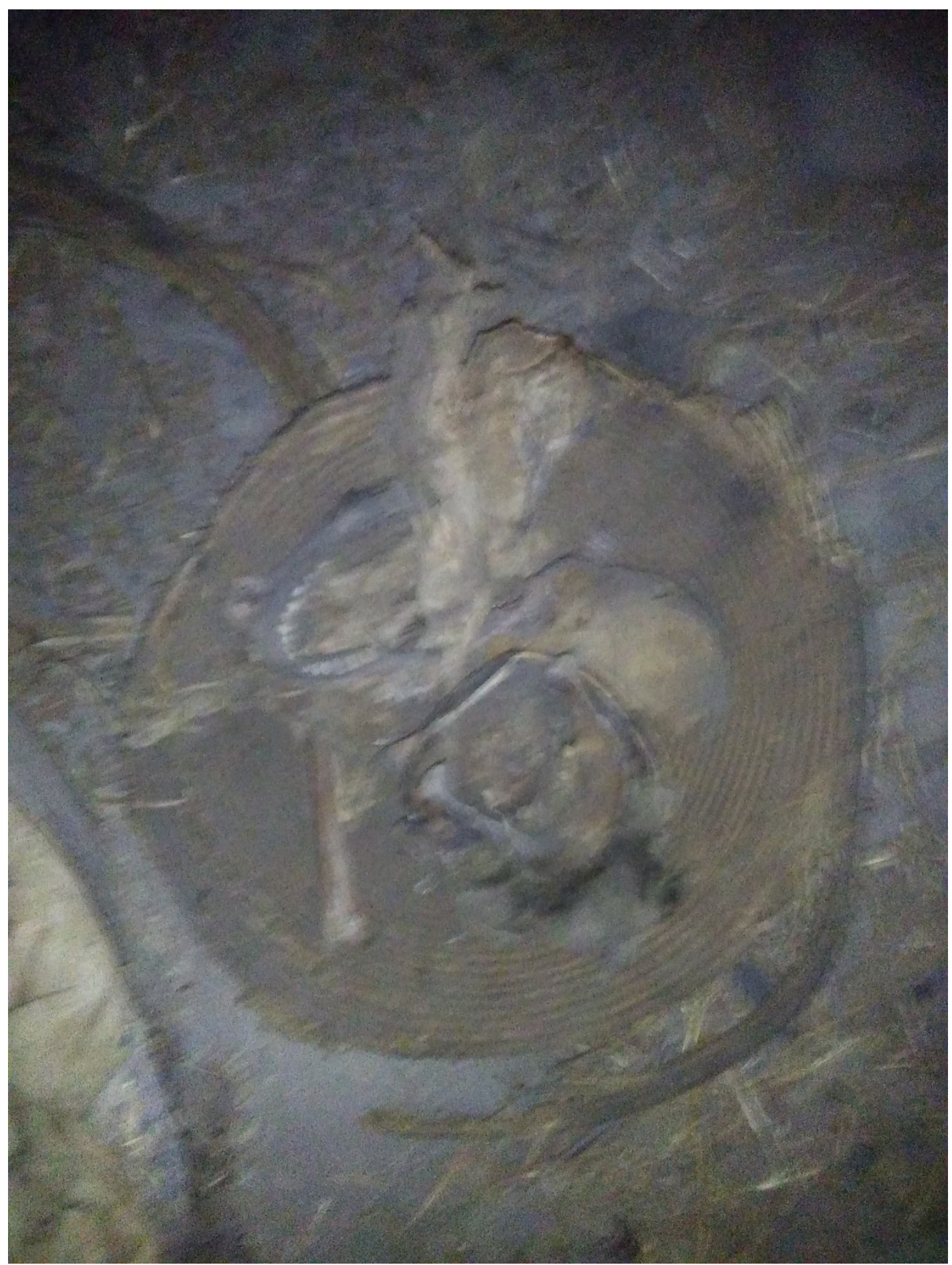




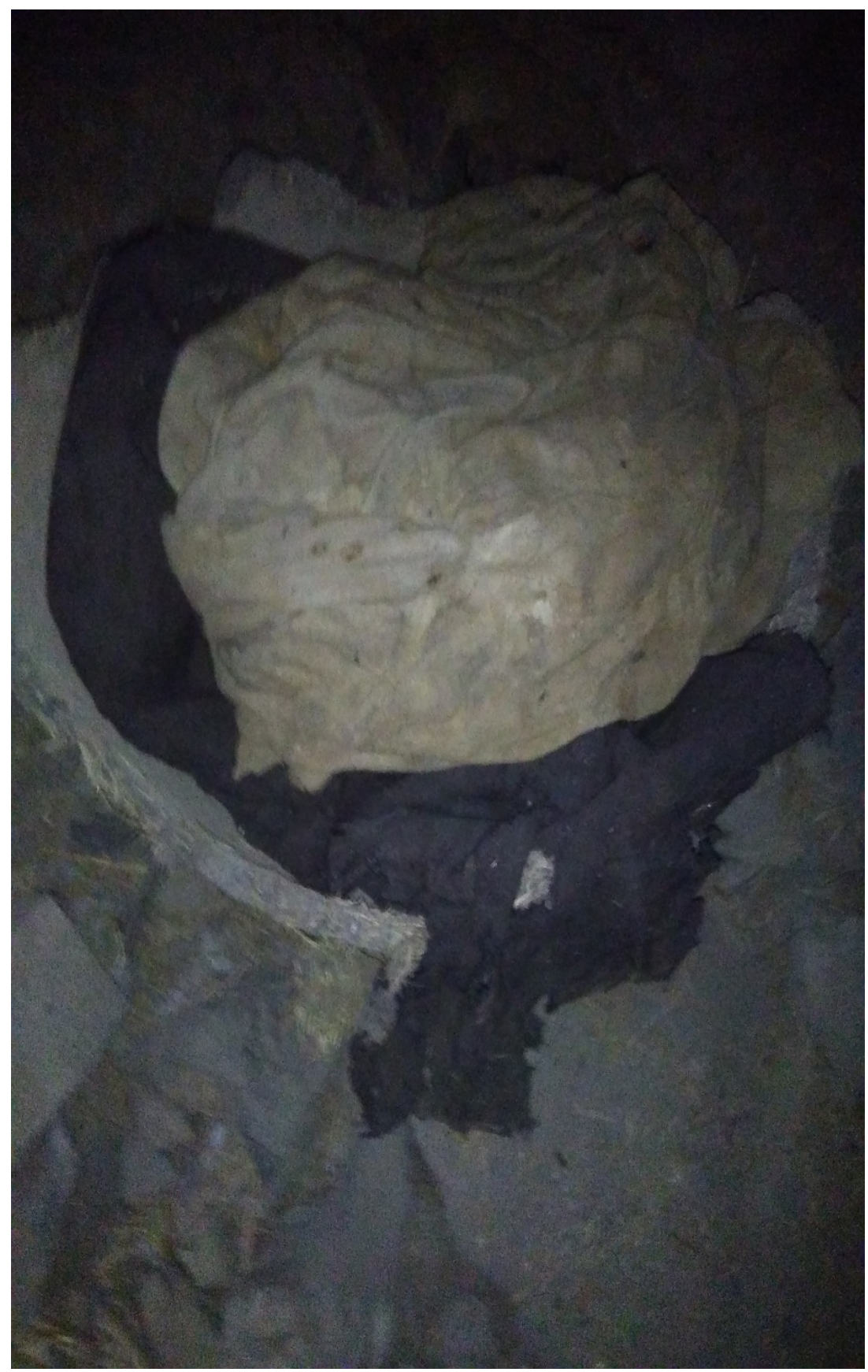




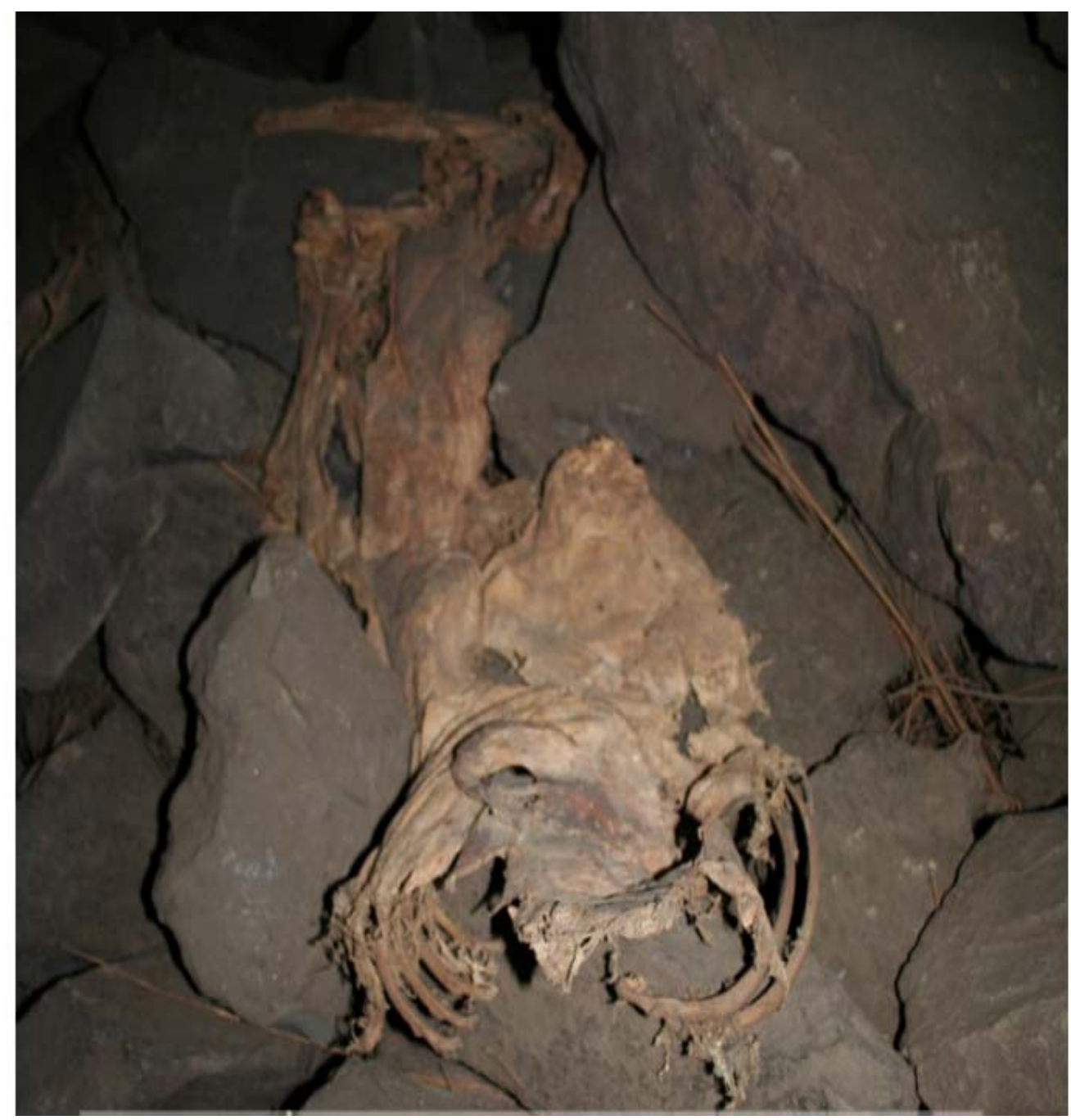


